University of Massachusetts Amherst

ScholarWorks@UMass Amherst

\title{
Profitability or Industrial Relations: What Explains Manufacturing Performance Across Indian States?
}

Anirban Karak

Department of Economics, University of Massachusetts, Amherst

Deepankar Basu

Department of Economics, University of Massachusetts, Amherst

Follow this and additional works at: https://scholarworks.umass.edu/econ_workingpaper

Part of the Economics Commons

\section{Recommended Citation}

Karak, Anirban and Basu, Deepankar, "Profitability or Industrial Relations: What Explains Manufacturing Performance Across Indian States?" (2017). Economics Department Working Paper Series. 217. https://doi.org/10.7275/9578217

This Article is brought to you for free and open access by the Economics at ScholarWorks@UMass Amherst. It has been accepted for inclusion in Economics Department Working Paper Series by an authorized administrator of ScholarWorks@UMass Amherst. For more information, please contact scholarworks@library.umass.edu. 


\section{DEPARTMENT OF ECONOMICS}

Working Paper

Profitability or Industrial Relations:

What Explains Manufacturing

Performance Across Indian States?

by

Anirban Karak

Deepankar Basu

Working Paper 2017-01

\section{UNIVERSITY OF MASSACHUSETTS AMHERST}




\title{
Profitability or Industrial Relations: What Explains Manufacturing Performance Across Indian States? ${ }^{1}$
}

\author{
Anirban $\mathrm{Karak}^{ \pm}$and Deepankar Basu
}

This version: January 23, 2017

\begin{abstract}
We use a state-level panel data set for the period 1969-2005 to analyze the relative importance of profitability (rate of profit) and industrial disputes (man-days lost to all industrial disputes per worker) in explaining cross-state variations of manufacturing sector performance in India. Using three different measures of manufacturing performance - net value added, investment and employment - we find that profitability is more significant than industrial disputes in explaining the variation of manufacturing sector performance across Indian states.
\end{abstract}

Keywords: manufacturing performance, profitability, industrial disputes

JEL Classification: B50, C26, O10

\footnotetext{
${ }^{1}$ Acknowledgement: The research for this paper was supported by a Chair's Summer Research Fellowship, Department of Economics, University of Massachusetts, Amherst.

${ }^{ \pm}$Department of Economics, University of Massachusetts, Amherst. Email: akarak@umass.edu

${ }^{\#}$ Department of Economics, University of Massachusetts, Amherst. Email: dbasu@econs.umass.edu
} 


\section{Introduction}

Economists have often envisaged an important role for the manufacturing sector in the structural transformation of an underdeveloped economy. While Lewis (1954) focused on the ability of manufacturing to absorb surplus labor from the traditional sector, Kaldor (1967) claimed that a fast growth rate of national income can only be achieved if a dynamic, fast-growing manufacturing sector leads the way. ${ }^{2}$ However, the actual experience of the Indian economy is quite different. Immediately after attaining independence in 1947, political leaders in India placed a great deal of emphasis on planned import-substitution industrialization (ISI) as the motor for economic development of the nation. Despite initial success - industrial growth averaged $7.6 \%$ per annum during the first 3 five-year plans between 1951 and 1966 (Ahluwalia 1991) stagnation in industrial (specifically manufacturing) production set in from the mid-1960s onwards (Srinivasan and Narayana 1977; Ahluwalia 1991). ${ }^{3}$ Although the performance of the manufacturing sector improved from the late 1970s and early 1980s onward, the recovery was less than spectacular and its contribution to real GDP increased only marginally. For example, the share of manufacturing value added in GDP during 1984, 1994 and 2005 was $14.90 \%, 16.06 \%$ and $17.08 \%$ respectively (Kotwal et al. 2011). Thus, even the high rates of GDP growth that India achieved during the period 1985-2005 was not on account of a dynamic manufacturing sector. Rather, the most significant

\footnotetext{
${ }^{2}$ Although Lewis (1954) speaks throughout of the 'modern' as opposed to the 'traditional' sector, manufacturing is certainly an important component of the modern sector. Moreover, the literature on 'patterns of development' has consistently emphasized that one of the observed empirical patterns is the increasing contribution of manufacturing to both GDP (in value added terms) as well as employment in the process of 'structural transformation' (Syrquin 1998).

3 Throughout this paper, our focus will be on the 'organized' manufacturing sector. The increasing proliferation of 'unorganized' manufacturing in recent decades necessitates a separate analysis of its evolution and its links with the organized sector through processes of ancillarization and subcontracting.
} 
contribution to overall growth was made by services: the value added share of services in GDP went up from $42.28 \%$ to $58.31 \%$ between 1984 and 2005 (Kotwal et al. 2011).

Nevertheless, the organized manufacturing sector in India today is quite significant in absolute terms. During 2012-13, the sector consisted of 222,120 factories employing 10 million workers. In the same year, the net value added by the sector amounted to 8602 billion Indian rupees - approximately 139 billion dollars - that accounted for about 10\% of India's GDP (Basu and Das, 2015). The launch of the "Make in India" campaign by Prime Minister Narendra Modi in 2014 indicates that the current administration is keen to emphasize the centrality of manufacturing to future economic development of the nation. Hence, it is important to have a clear understanding of the relative importance of different factors in the evolution of the organized manufacturing sector in India. Such an understanding can then inform policy decisions with regard to its future trajectory.

The literature on the evolution of Indian manufacturing industries is vast. In this paper, we focus on one particular aspect that has been discussed extensively in the more recent policy-oriented literature: the relationship between manufacturing performance and labor legislation (Fallon and Lucas 1993; Besley and Burgess 2004; Sanyal and Menon 2005; Aghion et al. 2006; Ahsan and Pagés 2009; Kotwal et al. 2011). Within this literature, it is possible to identify at least two related but distinct strands that differ with respect to their primary object of investigation.

First, during the early 1990s, one strand of literature developed with the aim of explaining the causes and consequences of "jobless growth" in Indian manufacturing 
during the 1980s. ${ }^{4}$ This literature emphasized the role of industrial relations within manufacturing units in determining output and employment. However, the climate of industrial relations was understood to be depending solely on labor legislation specifically the amendments to the Industrial Disputes Act (IDA) of 1976 and 1982. The central amendment to Chapter V-b of the IDA requiring employers in manufacturing establishments with more than 300 workers to acquire government permission before "lay-offs" and "retrenchment" was passed in $1976 .{ }^{5}$ In 1982, this amendment was extended to establishments with 100 workers. The literature that emerged in the 1990 s emphasized that these amendments made employers averse to hiring workers by making it difficult to fire them. The result was jobless growth (Fallon and Lucas 1993).

The early literature, represented by Fallon and Lucas (1993), used a "before-after" framework with regard to legislative changes in 1976 and 1982-84 to investigate the effect of industrial relations on manufacturing performance at the industry or all-India level. In the post-2000 period, an influential strand of literature has tried to use state-level variation in amendments to the IDA to explain the long-run variations in the performance of the manufacturing sector across states. The basic argument put forward by this literature is that states with a greater pro-worker tilt in labor legislation have fared worse in terms of manufacturing outcomes. In particular, it has been argued that pro-worker legislation increases the bargaining power of workers and thereby reduces the propensity

\footnotetext{
4 "Jobless growth" refers to the fact that while value added in Indian manufacturing grew at $6.3 \%$ during 1979-87, employment growth was negative and stood at $-0.3 \%$ (Bhalotra 1998, Table 1).

${ }^{5}$ The IDA defines a layoff as "the failure, refusal or inability of an employer on account of shortage of coal, power, or raw materials or the accumulation of stocks or the breakdown of machinery or natural calamity or any other connected reason to give employment to a workman whose name is borne on the muster rolls of his establishment." Layoffs are limited to 45 days on half pay. On the other hand, retrenchment is defined as "the permanent termination of a worker's service, other than on account of punishment, retirement, ending of a contractual period, or continued ill-health" (Bhattacharjea 2009).
} 
of employers to invest (Besley and Burgess 2004, pp. 102). However, the empirical procedure adopted and evidence marshaled for making such a claim have been criticized extensively (Bhattacharjea 2006, 2009; Kotwal 2011). In particular, Bhattacharjea (2006) has convincingly argued why the regulatory measure used by Besley and Burgess (2004) is flawed.

In this paper, we revisit the issue of explaining cross-state variations in manufacturing performance in terms of the industrial relations climate by focusing attention on two important issues. First, as our point of departure, we use the idea that intrinsic profitability of industries located in a particular state might be an alternative and independent determinant of cross-state variations in manufacturing performance. Second, we take Bhattacharjea's $(2006,2009)$ methodological critique of Besley and Burgess (2004) seriously, and so replace the regulatory measure that they construct with a more direct measure of the climate of industrial relations: total number of man-days lost to all industrial disputes (strikes and lock-outs).

What could justify using intrinsic profitability as a valid point of departure for our analysis? First, in the past, economists have emphasized the possibility that intrinsic profitability matters and that it might be an independent determinant of industrial performance. For example, in a paper focusing on the economic performance of the state of West Bengal, several prominent economists suggested that more than poor labor relations, the decline of the manufacturing sector in the state may have been caused by a decline in the "intrinsic profitability of industry in West Bengal" (Banerjee et al. 2002).

Second, the profit share - a key component of the rate of profit - is a measure of distribution of income between employers and workers. Thus, a rising profit share in the 
organized manufacturing sector, as found by Basu and Das (2015) for the period 1982-83 to 2012-13, is difficult to reconcile with high or growing bargaining power of labor, irrespective of pro-labor legislation. Thus, pro-labor legislation, to the extent it exists, might not translate into actual changes in the bargaining power of labor. Hence, using the former might lead to a mis-specified empirical model.

Finally, while the climate of industrial relations might certainly have a bearing on manufacturing performance, it might also be correlated with intrinsic profitability (which is also a plausible, independent determinant of manufacturing performance). Thus, failure to control for profitability while investigating the effect of industrial relations climate on manufacturing performance will give rise to biased results owing to an omitted variable bias.

In this paper, we use a state-level panel data set for the period 1969-2005 to analyze the relative importance of profitability and industrial relations climate as alternative determinants of manufacturing sector performance. Our analysis contributes to the extant literature in three ways. First, by econometrically analyzing the effects of profitability and industrial relations on manufacturing outcomes, we link together the concerns of three different sets of literature. The two literatures on "jobless growth" and cross-state variations in manufacturing outcomes have emphasized the role of industrial relations only in a narrow manner by focusing solely on labor legislation. More important, they have not incorporated profits and surplus distribution into their empirical exercises. We address this gap by incorporating profitability measures in our econometric model. The third literature that informs our paper is the one on profitability trends in Indian manufacturing that has looked at trends in the components of profit rates and their 
impact on investment but has left industrial relations out of the picture (Sau 1989; Felipe and Kumar 2010; Basu and Das 2015; Basu and Das 2016). We enrich the heterodox emphasis on the relationship between profitability and investment by explicitly accounting for industrial relations.

Second, our exercise has important policy implications. Based on econometric results, the literature focusing on labor legislation (Fallon and Lucas 1993; Besley and Burgess 2004; Ahsan and Pagés 2009) has argued that government regulation of labor markets has not always promoted social welfare. However, we must not hastily conclude that the policy aim should be to dismantle government regulation. Investment and output in the organized manufacturing sector certainly depend on profitability, since organized manufacturing in India is largely privately owned and capitalist in nature. ${ }^{6}$ Thus, if our results indicate a larger effect of profitability on manufacturing outcomes as compared to industrial relations, then removal of government regulation may not be the only or even the most important policy prescription.

Finally, our work can be linked to broader concerns regarding inequality in India, particularly in the neoliberal (post-1991) era. Using household level data on monthly consumption expenditure from the National Sample Survey (NSS), scholars have found that since 1991, inequality has increased between urban elites (such as enterprise owners, managers and professionals) and rural rentier classes (such as moneylenders and absentee landlords) on the one hand and urban workers, marginal farmers and landless agricultural workers on the other (Vakulabharanam 2010). More specifically, using the same NSS data, Basole and Basu (2015) have shown that in the post-1991 era, inequality within

\footnotetext{
${ }^{6}$ See Basu and Das (2016), particularly the introduction, for a good overview of the heterodox literature on the relationship between profitability and investment in capitalist enterprises.
} 
food and non-food group expenditures has declined, even as overall expenditure inequality has increased over time. They have argued that the rise in overall expenditure inequality is mainly driven by the share of non-food spending. This tends to be more unequal than food spending and has increased rapidly in the average household's consumption basket. Crucially, both Vakulabharanam (2010) and Basole and Basu (2015) have suggested that state provision of essential goods can mitigate inequality. Specifically, as economic growth picks up, the state can step in and improve public provisioning of education, health care, transportation and housing, since these services loom large as non-food items in household consumption. To the extent that profitability is found to be an important driver of investment in organized manufacturing, it further implies a very important role for the state in this regard, since a rising profit share - one of the components of the rate of profit - reduces the capacity of workers to access such services if they are privately provided. By using the profit rate as our measure of profitability, we analyze whether the distribution of income within manufacturing enterprises has indeed affected outcomes such as investment, net value added and employment. Although we do not analyze such links in detail in this paper, they are certainly an important avenue of future investigation.

Our empirical analysis shows that profitability is a more important determinant of industrial performance than industrial disputes. Our preferred specification suggests that a 1 per cent increase in the rate of profit is associated with a $0.7,0.6$ and 0.6 per cent increases in net value added, investment/capital stock ratio, and the number of workers employed. On the other hand, we find that a 1 per cent increase in the man-days lost to all industrial disputes is associated with 0.1 per cent declines in net value added and 
employment but no significant change in the investment/capital stock ratio. To us, this suggests that profitability is a more important determinant of industrial performance, both because it has numerically stronger effects (than industrial disputes) and because its effect is observable across a wider array of measures of industrial performance (than for industrial disputes).

The rest of the paper is organized as follows. In section 2, we undertake a critical review of the relevant literature. Our aim is twofold - to specify the limitations of existing work and to emphasize the manner in which we address it with our own empirical strategy. In section 3, we discuss details of our empirical strategy; in section 4,

we discuss our data sources, provide details about the construction of variables and discuss the main results of our analysis. The last section concludes the paper with some thoughts about future research.

\section{Literature Review}

The role of labor legislation in determining manufacturing sector performance was first emphasized during the attempts in the 1990s to explain the "jobless growth" of the 1980s. The pioneering study in this field was Fallon and Lucas (1993), who adopted a "beforeand-after" approach to identify the effect of labor legislation on manufacturing sector performance. Bhattacharjea (2006) proposes a general empirical model that can capture the essential points of the analysis in Fallon and Lucas (1993):

$$
N_{i t}=\beta_{0}+\beta_{1} X_{i, t}+\beta_{2} X_{i, t-1}+\beta_{3} N_{i, t-1}+\beta_{4} J_{t}+\beta_{5}\left(J_{t} \times N_{i, t-1}\right)+v_{i, t}
$$

where $i$ and $t$ indexes industry and year, $N$ denotes employment, $X$ is a labor demand variable (calculated through estimation of labor demand functions), and $J$ is a dummy variable that switches from zero to one in the year of legislative change. While 
$\beta_{3}$ measures the degree of inertia in the employment adjustment process, $\beta_{5}$ shows how the legal change affects the degree of inertia in (1). Using industry-level disaggregated data from the Annual Survey of Industries (ASI) that covered all manufacturing establishments employing 50 or more workers for the period 1959-82, Fallon and Lucas (1993) found both $\beta_{3}$ and $\beta_{5}$ to be insignificant. However, $\beta_{4}$ was found to be negative and significant, implying the legal changes did cause a significant reduction of $17.5 \%$ in employment. Hence, Fallon and Lucas (1993) identified job security legislation as the key factor causing the phenomenon of jobless growth. However, as argued by Nagaraj (1994) and Bhalotra (1998), there are several problems in the Fallon and Lucas (1993) analysis.

First, Fallon and Lucas (1993, pp.263) summarize their estimates as revealing a negative coefficient in 25 out of 35 manufacturing industries using a mere 25 percent level of significance. They conclude that the average drop in labor demand was 17.5 percent, but this figure is based on averaging across insignificant coefficients, which is a questionable procedure. Second, if the job security regulation had been of great importance, we would expect to observe threshold effects at 100 workers during the 1980s. ${ }^{7}$ Instead, employment growth was positive in factories with less than 1000 workers and negative only in larger ones (Nagaraj 1994).

A slightly different but related view of jobless growth was the assertion put forward by the World Bank (1989, Chapter 4) that the decline in employment during the 1980s was due to the acceleration in wages, which in turn was due to union-push. In a passing reference to employment, Ahluwalia (1991) reinforced this view. Thus, the

\footnotetext{
${ }^{7}$ Since the 1976 amendment was subsequently extended in 1982 (with effect from 1984) to establishments consisting of 100 workers.
} 
arguments made by Fallon and Lucas (1993) and the World Bank (1989) share an emphasis on labor's bargaining power. The assertion is that job security legislation provided greater bargaining power to workers that, in turn, led to a wage-push and subsequently to a fall in employment.

However, if job security made retrenchment harder and led to greater union power, it is hard to understand how employers could have fired workers in spite of that. ${ }^{8}$ Of course, this is not to deny that job security legislation affects employment decisions. Rather, it is to contest the rather simplistic view that such legislation is aimed at, or will necessarily lead to, an improved bargaining power of workers. Moreover, using ASI data, both Nagaraj (1994) and Bhalotra (1998) have established empirically that despite the fall in the number of workers employed, actual man-days worked increased during the 1980s. Nagaraj (1994) goes further and argues that if one looks at the growth rates of earnings per man-day rather than total earnings per worker, one can even counter the central claim of excessive wage growth during the 1980s. This is because earnings per man-day increased at a much slower pace, and in certain industries, it grew at rates that were even lower than the per capita growth of GDP during the 1980s. Thus, the "accelerating wage" argument for jobless growth does not hold up to careful empirical scrutiny.

Following the important critiques of Nagaraj (1994) and Bhalotra (1998), the attempt to understand the role of labor legislation in determining manufacturing outcomes took a slightly different turn. The intervention of Besley and Burgess (2004) has been influential in this regard. They exploited state-level variation in the direction of

\footnotetext{
${ }^{8}$ Bhalotra (1998) notes that a number of micro-studies found evidence of considerable evasion and bypassing of the law by firms (with the help of innovative methods).
} 
amendments made to the IDA during the period $1947-92$ for their analysis. ${ }^{9}$ First, they classified amendments as pro-worker, neutral or pro-employer, assigning scores of $+1,0$ and -1 respectively to each state for the relevant year. Second, they cumulated these scores over time to obtain a "regulatory index" for each state in each year. Finally, they used this index, along with control variables, to explain (with a one-year lag) state-level output per capita and employment in the organized manufacturing sector using a panel data set for 1958-92. They found that regulation in a pro-worker direction adversely affected two crucial outcomes - output and employment - for registered manufacturing. At the same time, pro-labor legislation promoted output in unregistered manufacturing. This led them to conclude that the domain of regulation - organized manufacturing - was indeed severely affected by amendments that improved the relative bargaining power of labor. However, the Besley and Burgess (BB) approach can be criticized on three separate grounds - the theoretical argument regarding the link between labor legislation and manufacturing performance, the suitability of the regulatory index as a measure of the industrial relations climate, and the econometric method. ${ }^{10}$

First, the arguments in BB do not provide much in the way of explaining why prolabor legislation should lead to poor manufacturing performance. In a short section titled

\footnotetext{
${ }^{9}$ Although the IDA was initially passed in 1947 as a Central Act, provincial governments had the authority to pass amendments as they deemed fit. This is what allows Besley and Burgess (2004) to analyze the relationship between state-level variations in labor legislation and manufacturing performance.

${ }^{10}$ It should be mentioned here that a number of studies have used variants of the regulatory index proposed by BB for different purposes. For example, Sanyal and Menon (2005) have used it to analyze the location of private investment across states while Aghion et al. (2006) have analyzed the interaction between delicensing of industries and labor legislation. Ahsan and Pagés (2009) have updated the BB index by disaggregating amendments into various classes and recoding some amendments in accordance with the suggestions of Bhattacharjea (2006). Since these studies follow the same general approach as BB and since our focus is on pointing out the limitations of that approach and suggesting an alternative econometric exercise, we do not discuss these studies in detail. Interested readers may refer to the comprehensive and insightful reviews of Shyam Sundar (2005) and Bhattacharjea $(2006,2009)$.
} 
"Theoretical Considerations," they mention two effects that are relevant for their analysis - a relative price effect and an expropriation effect. The relative price effect implies that pro-labor legislation will "raise the (fixed or marginal) cost of employing laborers" (BB 2004: 101). This will lead either to a rise in the capital-labor ratio or lower the firm's optimal output by increasing the marginal cost of production. The expropriation effect means that over time, if labor's bargaining power goes up, there will be lower returns on investment for employers as labor "expropriates" a larger portion of the rent or surplus. Thus, the key issue emphasized by BB is the possible increase in the relative bargaining power of workers due to pro-worker legislation.

Theoretically, the assertion that a relative price effect will lead to a rise in the capital-labor ratio conveniently assumes that the cost of capital (real interest rate) is constant. Empirically, there is no evidence to show that the "fixed or marginal cost of employing laborers" has gone up in manufacturing industries over time. Using a subset of the total organized manufacturing sector with data running from 1969 to 1986, Sau (1989) found a non-declining trend of the profit rate in India. More recently, using aggregate data from the Annual Survey of Industries, Basu and Das (2015) have analyzed the trends in both the profit rate and its different components - the profit share, the capacity utilization ratio and the capacity-capital ratio - in India's organized manufacturing sector between 1982-83 and 2012-13. Over the whole period of analysis, they have found that the rate of profit grew at about 1 percent per annum, primarily driven by a rising share of profits. As mentioned earlier, the analyses of Nagaraj (1994) and Bhalotra (1998) also cast doubt on the wage-push explanation of jobless growth 
during 1980s. Thus, for the entire period of analysis in our paper, there seems to be little evidence of a relative price effect of a rise in labor's bargaining power.

Regarding the expropriation of surplus by labor, the assertion by BB assumes that capitalists and workers have identical fallback positions. However, the fallback position of workers is crucially determined by factors such as the current levels of unemployment, inflation and the availability of credit and by the simple fact that the workers in manufacturing industries often have factory-specific skills that are of little or no use outside it. Thus, as Bhattacharjea (2006: 20) suggests, it would have been more appropriate to consider the reverse possibility - of capitalists expropriating a greater surplus from workers. Indeed, the rising profit share found by Basu and Das (2015) demonstrates the realization of such a possibility. In our own econometric exercise, we incorporate the profit rate as an explanatory variable to analyze the effects of the distribution of surplus within manufacturing establishments on net value added, investment and employment.

Second, although the theoretical emphasis by BB is on bargaining power, it is doubtful whether their regulatory index is a good measure of the same. In an important footnote, Besley and Burgess (2004: 99) mention that their index is highly correlated to the actual number of man-days lost to industrial disputes (strikes and lockouts); and this result is robust to the inclusion of state-specific time-trends unlike their other results. However, as Bhattacharjea (2006) points out, the basis for this relationship between de jure and de facto industrial relations is unclear. More importantly, careful empirical scrutiny reveals that this relationship is certainly tenuous at best if one undertakes a more disaggregated analysis. For example, as BB candidly admit, most of the amendments they 
study were passed post-1977. A quick count confirms that before 1976 (when the first Central amendment to the IDA was passed), only 31 out of the 113 state-level amendments studied were passed. Among them, only 5 were pro-labor and 3 of those were passed in Rajasthan, a state that is classified as pro-employer after the final cumulation. However, as various authors have noted (Rao 1995; Bhattacharjee 2001), it was precisely during the period 1965-1976 - the worst period of industrial slowdown that industrial disputes (particularly strikes) were at their peak. This is an important anomaly that also suggests the possibility of bi-directional causality between industrial performance and disputes. This discrepancy between legislation and actual occurrence of disputes is carried over to the decade of the 1980 s, when the majority of pro-labor amendments were passed. Surprisingly however, it was precisely during the 1980s that the share of lockouts in man-days lost to industrial dispute increased sharply (Shyam Sundar 2004; Bhattacharjee 2001). As mentioned before, the empirical claim of rising wages can be countered if one follows Nagaraj (1994) to argue that earnings per man-day did not witness a significant increase. Finally, the gap between legislation and outcomes is at its starkest if one looks at the 1990s. The last state-level amendment to the IDA was passed in 1989. If legislation were the sole cause of changes in relative bargaining power, then at the very least we would not expect to see any further changes in the composition of industrial disputes. However, as data from the Indian Labor Yearbook clearly shows, the share of lockouts in industrial disputes continued to steadily increase during the $1990 \mathrm{~s}^{11}$.

\footnotetext{
${ }^{11}$ As an aside, it should be noted that most studies analyzing the trend of growth rates in Indian manufacturing have found a structural break in the late 1970s or early 1980s (Kotwal 2011). Admittedly, the trend is for the whole of India while BB are trying to explain cross-state
} 
These anomalies probably follow from the problems in the construction of the $\mathrm{BB}$ index that Bhattacharjea $(2006,2009)$ points out - inappropriate classification, a lack of consideration of the relative importance of each amendment and a misleading cumulation over time. Indeed, these problems together lead to the curious classification of the state of Gujarat as pro-labor and the southern state of Kerala - one that is known for its socialdemocratic outlook and pro-poor policies - as pro-employer. Bhattacharjea (2009) also points out many examples to show that the extremely convoluted and tardy legal system in India means that it is almost impossible to say with any degree of certainty when exactly an amendment became operative in a particular state. All of this raises the question - what exactly does the BB regulatory measure capture? According to Bhattacharjea (2006: 32) -

“...it seems to capture, for the early 1980 s, the inter-state variation in some amalgam of labor regulation, industrial relations, and the investment climate."

Thus, it is not clear that the BB index is a good measure of labor's bargaining power, which is the cornerstone of their overall argument.

Therefore, in order to avoid the pitfalls of the BB index, we use a more direct measure of the climate of industrial relations: the actual quantum of man-days lost to strikes and lockouts in various states (normalized by employment). While this solves the problems associated with the $\mathrm{BB}$ index, it raises another challenge: the possibility of endogeneity. It is plausible to argue that there is a bi-directional causal relationship between manufacturing sector performance and industrial disputes (lockout and strikes).

variations in manufacturing performance. Nevertheless, this observation does not sit well with the fact that the lion's share of pro-labor legislation was passed in the 1980s. 
While a rise in industrial disputes might be expected to have a negative impact on manufacturing performance due to disruption in production, it is equally plausible to allow for a reverse causal effect. When there is slowdown or stagnation, the size of the pie shrinks and the struggle over its division - between capitalists and workers - becomes more acute. In a similar manner, industrial performance might also have a causal effect on profitability. It is possible that robust and high growth might provide incentives for firms to upgrade their technology and thereby enhance profitability. We address the valid concern of endogeneity in two different ways.

First, we use a flexible lead-lag specification to control for the possible causal impact on industrial performance on industrial disputes and profitability. This method controls for the possible impact of current industrial performance on future industrial disputes and profitability, and thereby blocks off the possible endogeneity arising from autocorrelation in the time series of industrial disputes and profitability. Second, we use a dynamic panel data model - with a lag of the dependent variable - as an alternative way of addressing the possible feedback from industrial performance to industrial disputes and profitability. We use the system GMM estimator to deal not only with the Nickel (1981) bias in such a setting but also possible contemporaneous reverse causal effects running from industrial performance to industrial disputes and profitability.

Finally, Bhattacharjea $(2006,2009)$ has also questioned the robustness of BB's econometric model. Specifically he has criticized the fact that BB use only the following control variables - a state's development expenditure, installed electricity generation capacity per capita, population and ruling political parties, as well as state and year fixed effects. He has argued that more indicators of state-level infrastructure and human capital 
should be included in the regression. In our econometric model, we address this lacuna by including several relevant control variables. As a measure of infrastructure, we continue to use installed electricity generation capacity per capita; as measures of the labor supply and (indicators of) its quality, we use the total population, literacy rate and social sector expenditure (health, education and other basic amenities) by state governments; and as indicators of the overall economic and political environment in a state, we use the per capita real net state domestic product (NSDP) and an index of ideological orientation of the coalition of political parties running state governments.

\section{Empirical Strategy}

\subsection{Econometric Model}

To test the relative importance of profitability and the climate of industrial relations in explaining the variation of manufacturing sector performance across Indian states, we use the following econometric model

$$
\log Y_{i t}=\beta_{1} \log \pi_{i t}+\beta_{2} \log I C_{i t}+\boldsymbol{\gamma} \boldsymbol{X}_{i t}+\mu_{i}+\delta_{t}+\alpha \times \phi_{i} t+u_{i t}
$$

where $i$ and $t$ indexes states and years, $Y_{i t}$ is a measure of manufacturing sector performance, $\pi_{i t}$ is a measure of intrinsic profitability, $I C_{i t}$ is a measure of the climate of industrial relations, $\boldsymbol{X}_{\boldsymbol{i}}$ is a vector of control variables, $\mu_{i}$ are state fixed effects, $\delta_{t}$ are year fixed effects, $\phi_{i} t$ denote state-specific linear time trends, and $u_{i t}$ refers to an unobserved stochastic error term.

For the analysis in this paper, we use three alternative measures of manufacturing sector performance as the dependent variable in (2): net value added, investment (normalized with the stock of fixed capital), and total workers employed. The key independent variables in (2) are profitability and the climate of industrial relations. We 
measure profitability by the rate of profit (flow of profit income divided by the replacement cost value of the stock of fixed capital), a standard measure used in the heterodox literature (see, for instance, Basu and Das, 2016). Our measure of the climate of industrial relations is the man-days lost to industrial disputes per worker, where industrial disputes refer to lockouts and strikes. Our primary interest is in the parameters, $\beta_{1}$ and $\beta_{2}$ in (2), which measure the partial effect of profitability and industrial disputes, respectively, on manufacturing sector performance.

To control for the effects of variables that might be correlated with manufacturing performance and with profitability and/or the climate of industrial relations, we include several control variables. To control for the state-level variation in infrastructure that is relevant for manufacturing sector performance, we include the installed capacity for electricity generation. This is motivated by the fact that we study the organized manufacturing sector, which uses electrical power as the key power input for its operations. To control for the general level of economic development, we include the real per capita NSDP. Among other things, it controls for the effect of aggregate demand on profitability and manufacturing sector performance. To make sure that our results are not confounded by any systematic variation in the size of states, we include the state-level population as a control. The level and quality of human capital can be an important determinant of manufacturing sector performance, but also of industrial disputes and profitability. Hence, we include the adult literacy rate and the total social sector expenditure per capita by state governments to control for these factors. Finally, to control for the possible impact of the ideological orientation of ruling parties or coalitions 
in state governments as a confounding factor, we include an index of political party ideology.

The model in (2) also includes state and year fixed effects. The former control for state-level, slowly-changing unobserved factors that could be correlated with manufacturing performance and profitability or industrial disputes, like cultural factors, attitudes of state-level bureaucracy, etc. The latter, year fixed effects, control for temporal shocks that would affect all states at any point in time, like global oil price shocks. We estimate the model in (2) with and without a full set of state-specific linear time trends. This is motivated by the fact that the results in BB were completely washed out as soon as state-specific trends were included (Besley and Burgess, 2004, column 4, Table IV). To make sure that our results are not confounded by the effect of any pre-existing state level trends, we report results that include state-specific linear trends in the model in (2). Thus, identification of the effect of profitability and industrial disputes in (2), in such specifications, occurs with respect to deviation from any pre-existing state-specific trends.

\section{Results}

\subsection{Data}

The data set used for the analysis in this paper is an unbalanced panel on the organized manufacturing sector for sixteen major states of India over the period 1969-2005. We assemble this state-level panel data set from different sources, details of which are available in the Appendix. We use three outcome variables for capturing manufacturing sector performance in the econometric model in (2): net value added, fixed investment (as a proportion of the replacement cost stock of fixed capital), and total number of workers. 
Data on these three variables come from the Annual Survey of Industries (ASI) and Besley and Burgess (2017), with the replacement cost capital stock series constructed using the methodology in Basu and Das (2016).

The key independent variables in our model in (2) are the climate of industrial relations and profitability. We use the total man-days lost to industrial disputes (strikes and lockouts) as our measure of the climate of industrial relations. Data on this variable comes from various issues of the Indian Labor Statistics and the Indian Labor Yearbook, both published by the Government of India. We measure profitability with the rate of profit, which is defined as the ratio of the flow of profit income over a year and the beginning-of-year stock of fixed capital (valued at replacement cost). These data also come from Besley and Burgess (2017) and the ASI.

Data on our control variables come from various sources. Data on total installed electricity capacity generation comes from Statistical Abstracts of India. Data on per capita real NSDP (2004-05 prices) come from the Handbook of Statistics on Indian Economy, an annual publication of the Reserve Bank of India. Data on state-level population is taken from the Economic Survey, an annual flagship publication of the Ministry of Finance, Government of India. Data on the adult literacy rate come from the Open Government Data Platform India. We construct the index of ideology of state governments using the methodology outlined in Barenberg, Basu and Soylu (2016, section 3.1).

\section{[Table 1 about here]}

Table 1 provides summary statistics for the variables used in the analysis in this paper. The logarithm of net value added (measured in units of crore, 10 million, of 
rupees) for the organized manufacturing sector varies, for the entire sample of state-years, from -1.09 to 11.61 , with a mean value of 7.35 ; similarly, the logarithm of investment (measured as percentage of the fixed capital stock) varies from -2.07 to 6.80 ; and, the logarithm of the number of employed workers varies from -2.90 to 7.21 . The logarithm of man-days lost to industrial disputes per worker varies from -0.21 to 15.87 , with a mean value of 7.62. The logarithm of the profit rate varies from -7.29 to 6.02 , with a mean value of 3.26. These data suggest a huge variation across state-years in manufacturing sector performance, industrial disputes and profitability. It is clear from Table 1 that all the control variables also display significant variation across state-years. This allows us to use the variation across states and years to estimate causal impact, to which we now turn.

\subsection{Main Results}

The main results of our analysis are summarized in Table 2 through 4 . Table 2 reports results of estimating the model in (2), where the dependent variable is the logarithm of net value added; in Table 3 and 4, we present results of estimating the same model, but with the log of investment (normalized by the stock of fixed capital) and the log of the number of workers, respectively, as dependent variables.

[Table 2 about here]

\subsubsection{Net Value Added as Measure of Industrial Performance: Basic Results}

The first column of Table 2 presents estimates for a stripped down version of the model in (2) with $\log$ of net value added as the dependent variable. In this version, the only regressors are the measure of industrial climate (logarithm of man-days lost to all 
industrial disputes per worker) and profitability (logarithm of the rate of profit), apart from state and year fixed effects. The coefficient on profitability is positive and statistically significant at the 0.1 per cent level; the coefficient on industrial disputes is negative and significant at the 1 per cent level. In column 2, we add the full set of controls: $\log$ of per capita net state domestic product (in fixed prices), log of the adult literacy rate, $\log$ of the installed electricity generation capacity, log of the population, and an index for the ideological orientation of the state government. When we add these controls, the coefficient on profitability increases a little and remains strongly significant; similarly, the coefficient on industrial disputes remains negative (and larger in absolute value) and significant.

Column 3 includes the full set of controls, state and year fixed effects and statespecific time trends. The coefficient on profitability is 0.672 and is statistically significant at the 0.1 per cent level. This means that a 1 per cent increase in the rate of profit is associated with a 0.672 per cent increase in the net value added. The coefficient on industrial disputes is -0.115 and statistically significant at the 0.1 per cent level. Thus, a rise in man-days lost to industrial disputes by 1 per cent is associated with a 0.115 per cent decline in net value added. These results show that profitability is quantitatively more important in determining industrial performance - measured by net value added than industrial climate - measured by the man-days lost to industrial disputes per worker.

\subsubsection{Net Value Added as Measure of Industrial Performance: Addressing} Concerns of Endogeneity

While the basic result presented in the first three columns of Table 2 show that profitability is a more important determinant of industrial performance than industrial disputes, there can be valid concerns about endogeneity. It is plausible that industrial 
performance - net value added - has a reverse causal effect on both industrial disputes and profitability. Industrial growth, by increasing the size of the pie, can reduce the likelihood of industrial conflict between employers and workers. Moreover, industrial performance can boost profitability through both demand and supply channels, a larger market and technological upgradation, for instance. To address concerns of endogeneity giving us biased estimates, we estimate two other specifications and report their results in columns 4 through 7 in Table 2.

In columns 4 and 5, we try to address the possible problem of reverse causality by including 1-lag and 1-lead of both industrial disputes and profitability in the basic model estimated in column 3 :

$$
\begin{aligned}
\log Y_{i t}= & \sum_{j=-1}^{1} \beta_{1 j} \log \pi_{i, t-j}+\sum_{j=-1}^{1} \beta_{2 j} \log I C_{i, t-j}+ \\
& \boldsymbol{\gamma} \boldsymbol{X}_{i t}+\mu_{i}+\delta_{t}+\alpha \times \phi_{i} t+u_{i t}
\end{aligned}
$$

While the lags are meant to capture possible delayed impacts of industrial disputes and profitability on industrial performance, the leads are meant to block the reverse causal channel that operated in a temporal sequence, i.e., industrial performance in the current period has an impact on industrial disputes and profitability in the next period. If industrial performance has a causal impact on industrial conflict (and profitability) in the temporal sequence sense, then that effect is likely to be picked up by the correlation between net value added in a period and industrial disputes (and profitability) in the next period. Since industrial disputes (and profitability) is likely to be persistent, this would make the error term correlated with industrial disputes (and profitability) and lead to an omitted variable bias. Including the lead of industrial disputes (and profitability) is meant 
to address this possibility. The basic result in column 3 remains valid in columns 4 and 5, but with a difference: the rate of profit has a positive and statistically significant impact on net value added, but the negative impact of industrial disputes is both numerically small and statistically weak.

While the results in columns 4 and 5 address concerns about endogeneity when they operate through temporal sequencing, the possibility of contemporaneous correlation between industrial performance and disputes (and profitability) remains a possible concern. To address this concern, we report results from estimating a dynamic panel data model in columns 6 and 7 of Table 2 of the following form:

$$
\begin{gathered}
\log Y_{i t}=\beta_{0} \log Y_{i, t-1}+\sum_{j=0}^{1} \beta_{1 j} \log \pi_{i, t-j}+\sum_{j=0}^{1} \beta_{2 j} \log I C_{i, t-j}+ \\
\boldsymbol{\gamma} \boldsymbol{X}_{i t}+\mu_{i}+\delta_{t}+\alpha \times \phi_{i} t+u_{i t}
\end{gathered}
$$

In model (4), we include 1-lag of the dependent variable in the basic model in (2) and also include 1-lag each of industrial disputes and profitability. The lag of the dependent variable is crucial and is meant to address two issues: first, it will capture the possible inertia in industrial performance (as emphasized in Fallon and Lucas (1993) and Bhalotra (1998)), and second, it will address concerns of reverse causality because it will capture the correlation between net value added in a period and industrial disputes (and profitability) in the next period. On the other hand, the lags of industrial disputes and profitability are meant to allow for delayed effects of these factors on industrial performance. While the model in (4) is useful to address the reverse causal channel from net value added to industrial disputes and profitability in a flexible manner, it adds a 
complication: the state fixed effects will be correlated with the lagged dependent variable, giving rise to Nickel (1981) bias.

To address this problem, we estimate the model with system GMM - the Blundell-Bond estimator for dynamic panel data models (Blundell and Bond, 1998). This method allows us to treat net value added (1-lag), industrial disputes and the rate of profit as endogenous, and uses two sets of internally generated instruments for GMM estimation: (1) first difference of net value added (1-lag), industrial disputes and the rate of profit as instruments in the levels equation; and (2) levels of net value added (1-lag), industrial disputes and the rate of profit as instruments in the difference equation. The results in columns 6 (without state-specific time trends) and 7 (with state-specific time trends) show that our basic results remain valid. The rate of profit has a positive and statistically significant effect on net value added - the coefficient is slightly higher than in previous columns. On the other hand, industrial disputes have a negative but numerically small (and statistically weaker) effect on net value added. The model with state specific time trends in column 7 of Table 2 is our preferred specification and shows that while a 1 per cent increase in the rate of profit is associated with a 0.655 per cent increase in net value added, a 1 per cent increase in man-days lost to industrial disputes reduces net value added by only 0.097 per cent.

\subsubsection{Investment and Employment as Measures of Industrial Performance}

In Tables 3 and 4, we report results that are similar to those reported in Table 2 but with different measures of industrial performance: in Table 3, we use log of the investmentcapital stock ratio, and in Table 4, we use log of the number of workers as the dependent variable. 
[Table 3 about here]

The results in Table 3 are similar to those reported in Table 2 but with one major difference: industrial disputes are not a significant determinant of investment. We see the following pattern across all specifications: the rate of profit has a positive and statistically significant effect on investment; industrial disputes have a negative (or even positive) but statistically weak effect on investment. For our preferred specification using a linear dynamic panel data model (with state-specific time trends) in column 7 , we see that a 1 per cent increase in the rate of profit is associated with a 0.595 per cent rise in the investment-capital stock ratio, and the effect is statistically significant at the 0.1 per cent level. On the other hand, changes in the man-days lost to industrial disputes have no statistically significant effect on investment.

[Table 4 about here]

In Table 4, we report results with log of the number of workers as the dependent variable (the measure of industrial performance). We see that the effect of the rate of profit on employment (number of workers) is quantitatively similar in magnitude and statistically similar in levels of significance to those reported in Table 2 and 3. Similarly, the effect of industrial disputes on employment of workers is also similar to those reported in Table 2. For our preferred specification in using a linear dynamic panel data model (with state-specific time trends) in column 7, we see that a 1 per cent increase in 
the rate of profit is associated with a 0.561 per cent increase in the number of workers, and the result is statistically significant at the 0.1 per cent level. On the other hand, the effect of industrial disputes is negative: a 1 per cent increase in industrial disputes (mandays lost to industrial disputes) is associated with a 0.092 per cent decrease in the number of workers, and this effect is statistically significant at the 1 per cent level.

\section{Conclusion}

To the best of our knowledge, this is the first study to take up the suggestion in Banerjee et al. (2002) seriously that what they call "intrinsic profitability" might be an independent and important factor to explain differential industrial performance across Indian states, in addition to or in place of the climate of industrial relations. Following their suggestion and connecting with a literature in heterodox macroeconomics, in this paper we have investigated the relative importance of the climate of industrial relations (measured as the total man-days lost to all industrial disputes) and profitability (measured as the rate of profit on the stock of fixed capital) on industrial performance across Indian states. Our analysis uses an unbalanced state-level panel data set from 1969 to 2005 for 16 major states. We find that profitability is a much more significant factor in explaining the variation of industrial performance - measured by net value added, investment/capital stock ratio, and total number of workers - across India's states than industrial disputes.

Our baseline specifications suggest that a 1 per cent increase in the rate of profit is associated with a 0.7 per cent increase in net value added, a 0.6 per cent increase in investment/capital stock, and a 0.6 per cent increase in the number of workers employed. All the three effects are statistically significantly different from zero. On the other hand, we find that a 1 per cent increase in the man-days lost to all industrial disputes is 
associated with a decline in net value added of 0.1 per cent, an insignificant change in investment/capital stock, and a decline of employment of workers by 0.1 per cent. This suggests that profitability is a more important determinant of industrial performance than the climate of industrial relations - the effect of the latter on investment is insignificant and on output and employment is numerically much smaller than the corresponding effects of profitability.

We would like to end by pointing out a possible weakness of the empirical analysis in this paper, and an avenue of future research. We have attempted to address concerns about endogeneity with two strategies: a lead-lag specification and a dynamic panel method. While these methods seem reasonable, it would be useful to try out other approaches for dealing with the possible problems of reverse causality. We explored one alternative approach to this issue by using two instruments for industrial disputes: unionization rate (log of the number of union members), and the inflation rate in the consumer price index for industrial workers (CPIIW). But these instruments turned out to be "weak" and so we did not report them in the paper - because weak instruments can increase the bias in the parameter estimates. Data on unionization is lacking for many state-years and when available it is not of good quality. Hence, other instruments need to be explored, something we have not been able to do in this paper.

To the extent that the results in this paper are reliable estimates of true effects, we show that profitability is an important determinant of industrial performance across states. Thus, the reason West Bengal has declined and Maharashtra has progressed in industrial development might have less to do with the climate of industrial relations than with profitability. Thus, an immediate question that calls for investigation is this: what 
are the important determinants of profitability of industrial firms across Indian states? Answering this question will enable the undertaking of a more meaningful approach towards policy-making than a sole focus on labor legislation. 


\section{$\underline{\text { References }}$}

Aghion, P., Burgess, R., Redding. S and F. Zilibotti (2006). 'The Unequal Effects of Liberalization: Evidence from Dismantling the License Raj in India.' Working Paper 12031, National Bureau of Economic Research.

Ahluwalia, I.J. (1991). Productivity and Growth in Indian Manufacturing. New Delhi: Oxford University Press.

Ahsan, A and C. Pagés (2009). 'Are All Labor Regulations Equal? Evidence from Indian Manufacturing.' Journal of Comparative Economics, 37(1): 62-75.

Banerjee, A. et al. (2002). 'Strategy for Economic Reform in West Bengal.' Economic and Political Weekly, 37(41): 4203-4218.

Barenberg, A., Basu, D., and Soylu, C. (2016). 'The Effect of Public Health Expenditure on Infant Mortality: Evidence from a Panel of Indian States, 1983-84 to 2011-12'. The Journal of Development Studies. Published Online, 16 October. DOI: http://dx.doi.org/10.1080/00220388.2016.1241384

Basole, A. and D. Basu (2015). 'Non-Food Expenditures and Consumption Inequality in India.' Economic and Political Weekly, 50(36): 43-53.

Basu, D. and. D. Das (2015). 'Profitability in India's Organized Manufacturing Sector: The Role of Technology, Distribution and Demand.' Working Paper, University of Massachusetts, Amherst.

Basu, D. and. D. Das (2016). 'Profitability and Investment: Evidence from India's Manufacturing Sector.' Metroeconomica (forthcoming).

Besley, T and R. Burgess (2004). 'Can Labor Regulation Hinder Economic Performance? Evidence from India.' Quarterly Journal of Economics, 119 (1): 91-134.

Besley, T. and Burgess, T. (2017). Economic Organization and Public Policy Program (EOPP) Indian States Data. Website.

Bhalotra, S. (1998). 'The Puzzle of Jobless Growth in Indian Manufacturing.' Oxford Bulletin of Economics and Statistics, 60(1): 5-32.

Bhattacharjea, A (2006). 'Labor Market Regulation and Industrial Performance in India: A Critical Review of the Empirical Evidence.' Working Paper No.141, Delhi School of Economics.

Bhattacharjea, A (2009). 'The Effects of Employment Protection Legislation on Indian Manufacturing.' Economic and Political Weekly, 44(22): 55-62.

Bhattacharjee, D. (2001). 'The Evolution of Indian Industrial Relations.' Industrial Relations Journal, 32(3): 244-263.

Blundell, R. and Bond, S. (1998). 'Initial Conditions and Moment Restrictions in Dynamic Panel Data Models.' Journal of Econometrics, 87:115-143.

Fallon, P. and R.E.B. Lucas (1993). 'Job Security Regulations and the Dynamic Demand for Labor in India and Zimbabwe.' Journal of Development Economics, 40(2): 241-75.

Felipe, J. and U. Kumar (2010). 'Technical change in India's Organized Manufacturing Sector.' Working Paper No. 626, Levy Economics Institute of the Bard College.

Kaldor, N. (1967). Strategic Factors in Economic Development. Ithaca: Cornell University Press.

Kotwal, A., Ramaswami, B. and W. Wadhwa (2011). 'Economic Liberalization and Indian Economic Growth: What's the Evidence?' Journal of Economic Literature, 
49(4): 1152-1199.

Lewis, W.A. (1954). 'Economic Development with Unlimited Supplies of Labor.' Manchester School of Economic and Social Studies, 22:139-191.

Nagaraj, R. (1994). 'Employment and Wages in Manufacturing Industries: Trends, Hypothesis and Evidence.' Economic and Political Weekly, 29(4): 177-186.

Nickel, S. J. (1981). 'Biases in Dynamic Models with Fixed Effects.' Econometrica, 49:1417-1426.

Rao, J.M. (1995). 'Capital, Labor and the Indian State,' in J. Schor and Jong-Il You (eds.) Capital, the State and Labor: A Global Perspective. Aldershot: Edward Elgar.

Saha, B. and I. Pan (1994). 'Industrial Disputes in India: An Empirical Analysis.' Economic and Political Weekly, 29(18): 1081-87.

Sanyal, P. and N. Menon (2005). 'Labor Disputes and the Economics of Firm Geography: A Study of Domestic Investment in India.' Economic Development and Cultural Change, 53: 825-54.

Sau, R. (1989). 'Falling Rate of Profit in India's Industry?' Economic and Political Weekly, 24(30): PE95-PE99.

Shyam Sundar, K.R. (2004). 'Lockouts in India, 1961-2001.' Economic and Political Weekly, 39(39): 4377-4385.

Shyam Sundar, K.R. (2005). 'Labor Flexibility Debate in India: A Comprehensive Review and Some Suggestions.' Economic and Political Weekly, 40(22/23): 2274-2285.

Srinivasan, T.N. and N.S.S. Narayana (1977). 'Economic Performance since the Third Plan and its Implications for Policy.' Economic and Political Weekly, Annual Number, February: 225 -239.

Syrquin, M. (1988). 'Patterns of Structural Change,' in H. Chenery and T.N. Srinivasan (Eds.) Handbook of Development Economics, Vol. 1. Amsterdam: North-Holland.

Vakulabharanam, V. (2010). 'Does Class Matter? Class Structure and Worsening Inequality in India.' Economic and Political Weekly, 45(29): 67-76.

World Bank (1989). India: Poverty, Employment and Social Services: A World Bank Country Study. The World Bank, Washington DC. 
Table 1: Summary Statistics for Pooled Sample

\begin{tabular}{lccccc}
\hline \hline & Mean & Std. Dev. & Min & Max & N \\
\cline { 2 - 5 } & 7.35 & 1.91 & -1.09 & 11.61 & 570 \\
Log Net Value Added (Rs. Crore) & 2.48 & 0.91 & -2.07 & 6.80 & 455 \\
Log Investment/Capital Stock (\%) & 5.55 & 1.06 & -2.90 & 7.21 & 570 \\
Log Workers (Thousands) & & & & & \\
Log Man-days Lost Due to Industrial Disputes & 7.62 & 1.43 & -0.21 & 15.87 & 554 \\
Per Worker & 3.26 & 0.73 & -7.29 & 6.02 & 518 \\
Log (Rate of Profit (\%)) & & & & & \\
& 9.74 & 0.68 & 5.97 & 12.27 & 647 \\
Log Per Capita Real NSDP (2004-05 Rupees) & & & & & \\
Log Installed Electricity Generation Capacity & 7.56 & 0.97 & 3.50 & 9.50 & 390 \\
(Thousand Kilowatts) & 9.85 & 1.58 & 5.35 & 11.83 & 621 \\
Log Population (Thousands) & 3.96 & 0.34 & 2.88 & 4.54 & 620 \\
Log Literacy Rate (\% of Adults) & 2.73 & 1.00 & 0.00 & 5.00 & 662 \\
Index of Ideology of State Government & & & & & \\
\hline
\end{tabular}

Source: Authors' Calculation. 


\section{Dependent Variable: Log Net Value Added}

Log Industrial Disputes (Man-days Lost)

Log (Rate of Profit)

State Fixed Effects

Year Fixed Effects

Controls

State-level Time Trends

Leads and Lags of Disputes, Rate of Profit 1-Lag Dependent Variable: System GMM

\begin{tabular}{|c|c|c|c|c|c|c|}
\hline (1) & (2) & (3) & (4) & (5) & (6) & (7) \\
\hline$-0.105 * *$ & $-0.151 * * *$ & $-0.115 * * *$ & $-0.037^{*}$ & -0.001 & $-0.116^{* *}$ & $-0.097 * *$ \\
\hline$(0.002)$ & $(0.000)$ & $(0.000)$ & $(0.011)$ & $(0.890)$ & $(0.001)$ & $(0.002)$ \\
\hline $0.577 * * *$ & $0.613^{* * *}$ & $0.672 * * *$ & $0.137 * *$ & $0.178 * * *$ & $0.639 * * *$ & $0.655^{* * *}$ \\
\hline$(0.000)$ & $(0.000)$ & $(0.000)$ & $(0.003)$ & $(0.000)$ & $(0.000)$ & $(0.000)$ \\
\hline Y & $\mathrm{Y}$ & Y & Y & Y & Y & $\mathrm{Y}$ \\
\hline \multirow[t]{5}{*}{ Y } & $\mathrm{Y}$ & $\mathrm{Y}$ & Y & Y & $\mathrm{Y}$ & Y \\
\hline & Y & Y & Y & Y & $\mathrm{Y}$ & Y \\
\hline & & $\mathrm{Y}$ & & Y & & Y \\
\hline & & & Y & $\mathrm{Y}$ & & \\
\hline & & & & & Y & $\mathrm{Y}$ \\
\hline 505 & 314 & 314 & 304 & 304 & 308 & 308 \\
\hline
\end{tabular}

Notes. Controls: log real per capita net domestic product, log of the adult literacy rate, log of installed capacity for electricity generation, log of population, an index of ideology of state governments. The models in (1) through (5) have been estimated with OLS, and model (6) and (7) has been estimated with system GMM. Pvalues, clustered by state, appear in parentheses below parameter estimates. Significance levels: $* * *<0.001, * *<0.01, *<0.05$. 


\section{Dependent Variable: Log Investment/Capital Stock}

Log Industrial Disputes (Man-days Lost)

\begin{tabular}{ccccccc}
$(1)$ & $(2)$ & $(3)$ & $(4)$ & $(5)$ & $(6)$ & $(7)$ \\
\hline 0.016 & -0.015 & 0.021 & 0.013 & -0.001 & -0.003 & 0.046 \\
$(0.683)$ & $(0.811)$ & $(0.686)$ & $(0.819)$ & $(0.991)$ & $(0.965)$ & $(0.471)$ \\
$0.708^{* *}$ & $0.963^{* * *}$ & $1.136^{* * *}$ & $1.113^{* * *}$ & $1.167^{* * *}$ & $0.519^{* * *}$ & $0.595^{* * *}$ \\
$(0.006)$ & $(0.000)$ & $(0.000)$ & $(0.000)$ & $(0.000)$ & $(0.000)$ & $(0.000)$ \\
$\mathrm{Y}$ & $\mathrm{Y}$ & $\mathrm{Y}$ & $\mathrm{Y}$ & $\mathrm{Y}$ & $\mathrm{Y}$ & $\mathrm{Y}$ \\
$\mathrm{Y}$ & $\mathrm{Y}$ & $\mathrm{Y}$ & $\mathrm{Y}$ & $\mathrm{Y}$ & $\mathrm{Y}$ & $\mathrm{Y}$ \\
& $\mathrm{Y}$ & $\mathrm{Y}$ & $\mathrm{Y}$ & $\mathrm{Y}$ & $\mathrm{Y}$ & $\mathrm{Y}$ \\
& & $\mathrm{Y}$ & & $\mathrm{Y}$ & & $\mathrm{Y}$ \\
& & & $\mathrm{Y}$ & $\mathrm{Y}$ & & \\
& & & & & $\mathrm{Y}$ & $\mathrm{Y}$ \\
441 & 262 & 262 & 257 & 257 & 221 & 221 \\
\hline
\end{tabular}

$\log$ (Rate of Profit)

State Fixed Effects

Year Fixed Effects

Controls

State-level Time Trends

Leads and Lags of Disputes, Rate of Profit 1-Lag Dependent Variable: System GMM

Observations

Notes. Controls: log real per capita net domestic product, $\log$ of the adult literacy rate, $\log$ of installed capacity for electricity generation, log of population, an index of ideology of state governments. The models in (1) through (5) have been estimated with OLS, and model (6) and (7) has been estimated with system GMM. P-values, clustered by state, appear in parentheses below parameter estimates. Significance levels: $* * *<0.001, * *<0.01, *<0.05$ 
Table 4: Effect of Industrial Disputes and Rate of Profit on Number of Workers

\section{Dependent Variable: Log Number of Workers}

\begin{tabular}{|c|c|c|c|c|c|c|c|}
\hline & $(1)$ & $(2)$ & (3) & (4) & $(5)$ & $(6)$ & $(7)$ \\
\hline \multirow[t]{2}{*}{ Log Industrial Disputes (Man-days Lost) } & $-0.119 *$ & $-0.162 * * *$ & $-0.141 * * *$ & $-0.053 *$ & $-0.036 * *$ & $-0.092 * *$ & $-0.092 * *$ \\
\hline & $(0.027)$ & $(0.000)$ & $(0.000)$ & $(0.011)$ & $(0.005)$ & $(0.003)$ & $(0.002)$ \\
\hline \multirow[t]{2}{*}{ Log (Rate of Profit) } & $0.370 *$ & $0.472 * * *$ & $0.529 * * *$ & 0.005 & 0.014 & $0.577 * * *$ & $0.561 * * *$ \\
\hline & $(0.014)$ & $(0.000)$ & $(0.000)$ & $(0.921)$ & $(0.597)$ & $(0.000)$ & $(0.000)$ \\
\hline State Fixed Effects & Y & $\mathrm{Y}$ & $\mathrm{Y}$ & Y & Y & $\mathrm{Y}$ & $\mathrm{Y}$ \\
\hline Year Fixed Effects & Y & $\mathrm{Y}$ & Y & Y & Y & $\mathrm{Y}$ & $\mathrm{Y}$ \\
\hline Controls & & $\mathrm{Y}$ & $\mathrm{Y}$ & Y & Y & $\mathrm{Y}$ & $\mathrm{Y}$ \\
\hline State-level Time Trends & & & $\mathrm{Y}$ & & Y & & $\mathrm{Y}$ \\
\hline Leads and Lags of Disputes, Rate of Profit & & & & Y & $\mathrm{Y}$ & & \\
\hline 1-Lag Dependent Variable: System GMM & & & & & & Y & $\mathrm{Y}$ \\
\hline Observations & 505 & 314 & 314 & 304 & 304 & 308 & 308 \\
\hline
\end{tabular}

Notes. Controls: log real per capita net domestic product, $\log$ of the adult literacy rate, $\log$ of installed capacity for electricity generation, log of population, an index of ideology of state governments. The models in (1) through (5) have been estimated with OLS, and model (6) and (7) has been estimated with system GMM. P-values, clustered by state, appear in parentheses below parameter estimates. Significance levels: $* * *<0.001, * *<0.01, *<0.05$ 


\section{Appendix: Data Sources and Construction of Variables}

The unbalanced panel dataset used for the analysis in this paper were constructed from many different sources. For the 37-year period 1969-2005, we cover the following sixteen major states of India - Andhra Pradesh, Assam, Bihar, Gujarat, Haryana, Jammu \& Kashmir, Karnataka, Kerala, Madhya Pradesh, Maharashtra, Orissa, Punjab, Rajasthan, Tamil Nadu, Uttar Pradesh and West Bengal. In 2001, three more states - Jharkhand, Chattisgarh and Uttarakhand were created from the erstwhile states of Bihar, Madhya Pradesh and Uttar Pradesh respectively. We have merged the post-2001 observations for the corresponding states to get a consistent series for sixteen states for the entire period 1969-2005.

For our measures of industrial performance - net value added, investment/capital stock, and number of workers employed - the primary source of data is the Indian Annual Survey of Industries (ASI). The ASI is one of the most reliable sources of information regarding various aspects of the manufacturing sector in India and has been conducted every year by the Central Statistical Office (CSO) of the Government of India since 1959 (except 1972). The ASI covers all factories registered under sections 2(m)(i) and 2(m)(ii) of the Factories Act of 1948 wherein a factory, the primary statistical unit of enumeration, is defined as any premise where a manufacturing process is carried out by 10 or more workers working with the aid of power, or 20 or more workers working without power. The ASI sample is divided into two parts - a census sector and a sample (or factory) sector. The census sector involves full enumeration covering all industrial units in 5 less industrially developed states - Manipur, Meghalaya, Nagaland, Tripura, and Andaman \& Nicobar Islands - and all units having 100 or more workers in the other 
states and union territories (UTs). The sample sector involves stratified random sampling of units in states other than those considered industrially less developed.

Our data on Net Value Added (NVA) is from the ASI and is defined as the increment to the value of goods and services that is contributed by a factory and is obtained by deducting the value of total inputs and depreciations from the value of output. For the years 1980-2008, we have used the data on the factory sector directly from ASI publications. For the period 1969-1979, we have used the data collated by Besley and Burgess (2004) and made available online by the Economic Organisation and the Public Policy Programme (EOPP) of the London School of Economics and Political Science (Besley and Burgess, 2017).

Data on employment has also been taken from the ASI. We use the data on the total number of workers as our measure of employment. Again, for the period 1980-2008, we have obtained the numbers directly from ASI publications and for 1969-1979, we use the data from the EOPP website.

Finally, for our third dependent variable - investment - we use slightly different measures for two different periods. For 1980-2005, we measure investment as the ratio of net fixed capital formation (NFCF) and the stock of fixed capital (at the beginning of the period). The data on NFCF comes from the ASI, which also reports the stock of fixed capital on the basis of historical cost valuation. We use the following recursion to compute replacement cost capital stock: $\mathrm{K}(\mathrm{t}+1)=\mathrm{K}(\mathrm{t}) \times[\mathrm{P}(\mathrm{t}) / \mathrm{P}(\mathrm{t}-1)]+\mathrm{I}(\mathrm{t})$, where $\mathrm{K}(\mathrm{t})$ is the value of replacement cost capital stock at the beginning of period $t, I(t)$ is the net fixed capital formation over period $t$, and $\mathrm{P}(\mathrm{t})$ is the value of the national wholesale price index for machines and machinery (WPIMM) in period $t$. In the initial period, $t=0, K(0)$ 
is the historical cost value of capital stock. This methodology has previously been used in Basu and Das (2016). Unfortunately, since the data on NFCF is not available for the preceding years, for 1969-1979, we measure investment as the change in fixed capital stock every year. Again, we calculate the fixed capital stock at replacement cost using the WPIMM. The data on the stock of fixed capital for the period 1969-1979 comes from the EOPP website. The data on the WPIMM for the entire period 1969-2005 comes from the Office of the Economic Adviser, Department of Industrial Policy and Promotion, Ministry of Commerce and Industry, Government of India.

The independent variable that captures the industrial relations climate is the total number of man-days lost in industrial disputes. Data on this variable comes from various issues of the Indian Labor Statistics and the Indian Labor Yearbook, both published by the Labor Bureau, Ministry of Labor and Employment, Government of India.

We measure profitability using the rate of profit, which is computed as the ratio of profit income and the stock of fixed capital (measured in replacement cost) at the beginning of the year. We calculate profit income as the difference between Net Value Added and Wages of productive workers. Data for these variables come from the EOPP website (1969-1989) and the ASI (1980-2005).

For our control variables, the sources are as follows: data on total installed electricity generation capacity were taken from the Statistical Abstracts of India, Central Statistical Office, Department of Statistics, Ministry of Planning, Government of India; data on per capita real NSDP (at 2004-05 prices) are taken from the Handbook of Statistics of Indian Economy, an annual publication of the Reserve Bank of India; data on state-level population for Census years are taken from various issues of the Economic 
Survey, the annual flagship publication of the Ministry of Finance, Government of India for other years, data was generated with linear interpolation; data on the index of ideology was taken from Barenberg, Basu and Soylu (2016). 